\title{
Pentecostalism \& schisms in the Reformed Church in Zambia 1996-2001; evidence from documentary sources ${ }^{1}$
}

\begin{abstract}
This article is descriptive in nature and a practical theological assessment of the schisms that took place in the Reformed Church in Zambia (RCZ) between 1996 and 2001. It analyzes the available documents to find an answer to the question why it happened. Pentecostal/charismatic tendencies have challenged the long inherited tradition of mainline churches in general and the RCZ in particular. Subsequently, Pentecostal/charismatic movements have caused intense conflict in the church between the pro-conservatives and pro-Pentecostals. In the RCZ this led to the formation of the Christian Reformed Church (CRC) in 1999 and the Bible Gospel Church in Africa (BIGOCA) in 2001.
\end{abstract}

\section{INTRODUCTION}

The article is a practical theological assessment of the schisms in the Reformed Church of Zambia (RCZ) that took place between 1996 and 2001. It focuses on the causes of the infighting in the Church that resulted in two break-away churches. The research was undertaken because of the researchers' interest to do an in-depth investigation and analysis of schisms in the RCZ. The research reported on in this article concern the primary church documents in Lusaka that helps one to understand what happened and why the schisms took place. The researchers believe that a better understanding of the cause of the infighting and differences in worship can help the Church's leadership to develop preventive strategies.

\section{2.}

\section{THE RESEARCH PROBLEM}

The RCZ experienced two schisms that followed each other within a period of five years. The first started in 1996 and continued to 1999, when a minister was expelled and a number of members followed him. They formed their own Church called the Christian Reformed Church (CRC). The first split started as a small constitutional matter. The presbytery leadership accused the Mtendere congregation of insubordination when they rejected the minister whom the Synod had sent to them. The presbytery insisted that the Synod's authority was final and nonreversible.

In 2001, nine ministers in nine RCZ congregations were expelled, together with those members who supported their new worship practices. They formed the Bible Gospel Church in Africa (BIGOCA). The second schism started as a violation of the Church's tradition on worship. In urban areas, many congregations started new ways of worship. Individual ministers in various congregations started what was perceived as a violation of the established liturgical order that was gradually being abandoned. It was replaced with altar calls, singing of choruses and the

1 The paper is based on Chapter 4 of the doctoral dissertation of Lukas Soko (2010:81-120). Prof Hendriks was the study leader. 
clapping of hands, dancing, skipping of the Lord's Prayer, repeated shouting of "hallelujah" and "amen," mass prayers, and speaking in tongues. Thus, the constitution of the Church was refuted (Soko 2010:81-104).

Up to the end of the research project (2010), the Church has not yet attended to the root causes of the problem. Why did the Church leadership fail to handle the conflict and prevent the split?

3. SOCIOLOGICAL DIMENSION

The RCZ is one of the oldest pioneer churches in Zambia. In 1899, the Dutch Reformed Church (DRC) missionaries founded it in the Eastern part of Zambia (Verstraelen-Gilhuis 1982). From a small missionary endeavour, the Church has grown with its membership cutting across cultural barriers. The RCZ has its administrative headquarters in Lusaka, the capital city of Zambia. The motivation to do this research emerged from the researchers' direct involvement, one as a serving minister at the time of the split, the other through $\mathrm{NetACT}^{2}$.

4.

\section{PRACTICAL THEOLOGICAL METHODOLOGY}

The research was conducted as a practical theological study. The studies of Heitink (1999), Studies in Practical Theology: History, theory, action domains, and Hendriks (2004), Studying congregations in Africa, were used. In this definition, they state that the Christian faith is embedded in the traditions of the community of faith. During the first century of the RCZ's existence radical political, economic and social changes took place challenging its inherited traditions.

The descriptive and analytical dimensions of the research captured the perspectives of what the RCZ understood to be the causes of the schisms, as substantiated in their official documents, and as opposed to a generalization of the problem. To capture this data, the researchers studied official Church documents such as minutes, letters that were written and still available and also the print media such as local newspapers.

The Church documents are:

(1) Synodical minutes from the RCZ archives at the JMTUC in Lusaka.

(2) Presbytery minutes from three presbyteries, namely Chelstone, Kamwala and Matero

(3) Congregational council minutes from six congregations, namely Chaisa, Chawama Central, Chelstone, Garden, Mtendere and Matero

(4) General correspondence with Church members.

(5) Print media such as the local newspapers.

The value of this research is to provide a descriptive and practical-theological assessment of the RCZ schisms, relevant to the understanding of one of the most salient contemporary issues in the church in Africa (Cox 1995:243-262; Kalu 2008). Note has been taken of the fact that this kind of schism either takes place within congregations or between large bodies of Christian faith that all impact on the church's mission. The institutional model of being a church is facing immense pressure to change. The research aims to assist church leadership to understand what happened and why it happened in order to be able to deal with the phenomenon. However, the research was demarcated in a decisive way: it stays descriptive and does not attend to Pentecostal theology and its growth in Africa. It set out to establish what happened in Lusaka

2 http://academic.sun.ac.za/theology/netact.html (downloaded 7 Dec 2010) 
in order to have the baseline facts verified. The phenomenon of Pentecostalism in Africa ${ }^{3}$ is the broader framework against which this took place. As such this descriptive research needs to be complemented by research describing the deeper theological roots of the movement.

\section{DOCUMENTARY SOURCES AND CHURCH GOVERNANCE}

The documents and literature related to the RCZ must be understood and applied since they describe the governance of this Church. The polity of the RCZ recognizes its three councils, namely the congregation, presbytery, and the Synod (The constitution, bylaws and procedures of the RCZ, 2004 Articles 9, 21, 23, 24, 26: 5-16). These councils are responsible for the Church's management and welfare at their respective jurisdictional levels, including the administration of discipline in accordance with their character and authority, granted by the council.

The congregational council has two types of council meetings: the serving elders and deacons who meet on a monthly basis to administer the affairs of the congregation, while both the serving and resting elders and deacons usually meet twice a year. The resident or visiting minister chairs both of these meetings.

The second council is that of the presbytery that consists of all ordained but serving ministers in congregations within the boundaries of a presbytery, as well as one elder from each of the congregations. Presbytery councils meet once a year between March and April. The synod council, which meets every two years, has a representation of delegates, that is, all serving ministers and one serving elder from each congregation.

\section{6.}

\section{PENTECOSTAL TENDENCIES IN THE RCZ}

The influence of Pentecostal tendencies in the RCZ seems to have started among the clergy in 1992 (Dziwani, ${ }^{4}$ 7:20 January/February 1994:14). One senior minister, Rev Samuel Phiri, claimed to have met Jesus on 16 November 1992. He then confessed his sins publicly. Much of his confession concerned his extra-marital relationships with women in the Church. The Church leadership was perturbed about what he had publicly confessed. Arising from his public confession, the synod leadership suspended him for a year. Because of this suspension, he resigned from the RCZ and joined a break-away group called "Grace Ministries," believed to have broken away from the United Church of Zambia (RCZ Synod Pastoral Letter, ${ }^{5}$ 13-18 August 1996:3).

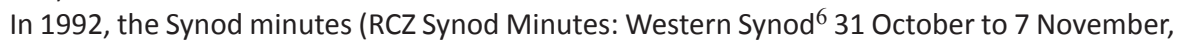
1993:21) reported that 33 youths from the Matero Presbytery had left the RCZ to join other churches. Differences between the youth and the Church leadership concerning the RCZ's

3 Missionalia 35:3 (Nov 2007) deals with the theme: "The Pentecostalisation of African Christianity."

4 Dziwani was a newsletter of the RCZ that the communication department managed. It mostly contained news and information of the activities and developments in the Church.

5 A Pastoral Letter in the RCZ is an official document containing the resolutions passed at the Synod and presbytery meetings. Their contents are not subjects for members or congregations' discussion - only for the Synod or presbytery. Resolutions contained therein are of immediate effect.

6 In 1991, the RCZ's Synod Meeting had an item on its agenda to have two Synods (Synod Minutes: 25 August to 1 September 1991). The result was as follows: 117 delegates voted in favour of the item on the agenda, and 14 opposed the motion. With this outcome, the RCZ was divided into two Synods: the Eastern and Western Synods. This meant that all congregations west of the railway line became part of the Western Synod, covering eight provinces. The Eastern Synod had only one province, that of the Eastern Province. The regional Synod would meet in the years between the meetings of the General Synod. On 22 December 1994, the Regional Synods were again abolished. 
doctrine were reported to have caused the exodus of these youths. They (the youth) had demanded further clarification on issues, such as infant baptism, the mode of baptism, the baptism of the Holy Spirit, Holy Communion, overnight prayers, praying for the sick and demon exorcism. These doctrinal issues caused much confusion and tension. The Matero and Mtendere congregations then banned the entire youth groups from their respective congregations. Ministers and their elders perceived these youth groups as unpatriotic and insubordinate to the authority and teachings of the RCZ (RCZ Synod Minutes: Western Synod 31 Oct. to 7 November, 1993:21).

An impression seems to have been created in 1996 that the growth of Pentecostal and charismatic tendencies ${ }^{7}$ were spreading in the RCZ (Dziwani 11:28 1996:21; Correspondence: Rev. Japhet Ndhlovu 22 February 1996; Rev. Rodgers Nkhuwa 19 March 1996; and Rev. Cephas M. Mbewe 28 March 1996). Rev. Japhet Ndhlovu, then from the Kamwala congregation in Lusaka and Rev. Rodgers Nkhuwa, then the Youth Director of the RCZ based in Lusaka, both aired their concerns to the Synod's moderator, Rev. Edwin M. Zulu. Their separate letters to the moderator were titled as follows:

"Protest against the infusion and growth of Pentecostalism theologies and practices"

(Japhet Ndhlovu: correspondence 22 February, 1996);

"My concern over the growth and tendencies of Pentecostalism and charismatic theologies

in our Church" (Rodgers Nkhuwa: correspondence 19 March 1996).

Both ministers expressed shock that "Reformed Pastors" in the Church were perpetuating Pentecostal tendencies. They were allegedly performing practices associated with Pentecostalism without being checked, and some congregations were in support of it while others were confused by what was happening in the Church. The two, Ndhlovu and Nkhuwa, made their concerns clear that, if these tendencies were not checked and addressed, they had the potential to lead to divisions in the RCZ. The two ministers made a number of concerns and suggestions to the moderator. Rev. Ndhlovu's concerns were (Japhet Ndhlovu: Correspondence 22 February 1996):

"Where are we heading as a Church with this emerging crisis?

"What should we do or should be doing about particularly pastors who are in the forefront of promoting these theologies and practices?

"What about those students at Justo Mwale Theological College who seem to be never changing to Pentecostal theologies and practices as they are training?"

Rev. Nkhuwa suggested (Rodgers Nkhuwa: Correspondence 19 March 1996):

"That the Church must revisit its confessions of faith by openly and clearly admitting that it had errored and would like to start afresh.

"That all the serving ministers in RCZ to be made to reaffirm "Chibvomerezo chotsimikizira Abusa"

"That all students at Justo Mwale Theological College be taught deliberately the Reformed heritage in total.

"That the Theological and Current Affairs Committee be reorganised so that it could march with time and address issues that had crept in the Church unchecked."

By the dates of the correspondence, one can deduce that the Church started to experience

7 Pentecostal and charismatic tendencies in the RCZ were witnessed in the way the traditional elements of the liturgy were being discarded. The initial experiences were phenomena such as speaking in tongues, prophecies, visions, healing, and miracles, that became part of the worship service. Those who promoted the foreign practices were called, "Pentecostals" and those supportive of the traditional liturgy, "Adutch." 
these waves prior to 1996. In 1995, Paradise congregation wrote to the Matero Presbytery leadership complaining about pastors who were bringing confusion to the Church with foreign practices, such as mass praying, speaking in tongues, overnight prayers and healing sessions (Correspondence: Paradise congregation: 26 December 1995). The congregation pleaded with the Presbytery leadership to hasten in finding a lasting solution (Chonde tithandizeni pankhani iyi chifukwa chipembezo cha chilendo chatenga malo mu RCZ).

Until 2001, the problems concerning these new waves continued to cause disunity in the Church (Correspondence: Chelstone Presbytery 11 October 1999; 12 January 2000; High Court of Zambia: correspondence 11 May 2000; Times of Zambia: 9 May 1997, 31 January 2000, 8 February 2000, 2 January 2001; National Mirror No. 869: 27 January-2 February 2001; The Post: 7 March 2001).

By and large, the years that preceded the 1996 to 2001 period were the most significant in the RCZ's history. What was the position of the Synod at this stage? When did the crucial events of Pentecostalism start to appear on the Synod agenda? Fortunately, 1996 was the normal calendar year for this meeting. The Church had its successive Synod Meetings in 1996, 1998, 2000, 2002, 2004, 2006 and 2008. In between these years, two Extraordinary Synod Meetings were held - in 1999 and in 2001. The case for Mtendere was concluded during the 1999 Extraordinary Synod Meeting, and the 2001 meeting was called solely to discuss the way forward for the RCZ that faced a looming split

\section{ON THE SYNOD AGENDA: PENTECOSTAL PRACTICES - THE RCZ'S DILEMMA}

Although a comprehensive source that describes Pentecostal practices in the RCZ is not available, an examination of the resolutions passed, the minutes and reports of the 1996, 1998 and 2000 Synod meetings are crucial for understanding how the Church viewed the Pentecostal tendencies. The recommendations and resolutions of these Synods eventually led to an Extraordinary Synod Meeting in 2001 that finally excommunicated nine ministers from the Church and initiated a break-away Church. During these Synod meetings, the profile of the RCZ was as follows: in 1996, there were 138 congregations and 96 pastors; in 1998 the number of congregations rose to 145 with 74 pastors, and in 2000 there were 148 congregations and 82 pastors (RCZ Pastoral letter, 13-18 August 1996; RCZ Synod Reports: 21-29 August 1998; RCZ Synod Minutes: 21-25 August 2000; 27-31 August 2002).

At the 1996 Synod held from 13 to 18 August 1996 in the Katete Secondary School at the Mphangwe congregation, Eastern Province, the question of Pentecostalism was a point on the agenda. A report by one of the working synodical committees initiated this discussion (RCZ Synod Minutes: 13-18 August 1996:43).

However, after a lengthy discussion about the question of Pentecostal/ charismatic movements in the report called "The Kairos Movements' document," the Synod made the following observations (RCZ Synod Minutes, 1996:47):

"That, those Pentecostal tendencies in the Church had generated a lot of interest among the delegates.

"That Synod should continue teaching on the understanding and interpretations of Pentecostal and Charismatic tendencies from a theological point of view.

"That the Church should guard against emotionalism and personal fulfilling experiences.

"That Synod must accept and recognise the gifts of the Holy Spirit - Romans 12.

"That there should be orderliness whenever these are practiced in the Church.

"That the Altar Calls should be done on the rightful occasion."

When all the observations were made as a measure to accommodate these tendencies, the 
Synod made two recommendations:

"That the Theological and Current Affairs committee do research on the doctrine of the Holy Spirit and present its report to the Synodical Committee.

"That all councils in the Church should seriously teach on the subject matter to avoid heretical practices in the Church."

A question of interest is: What exactly did the Synod view as "Pentecostal tendencies" that needed further investigation? Many claims were made in the Synod about such tendencies. Some of these unusual practices were: singing of choruses, mass praying, the minister's altar calls immediately after preaching, speaking in tongues, crying, jumping up and down, scratching the walls, beating of chests, and all kinds of movements. "Pandemonium" was the term used to describe these services. "As the spirit leads" became the order that characterized the Sunday services.

In 1998, the Theological and Current Affairs Committee (TCAC) presented its findings to the Synod meeting held at Ndola Rehabilitation Centre in the Copperbelt from 21-29 August 1998 (RCZ Synod Reports 1998:56). The report had the heading, "Dynamic worship in the RCZ by the year 2002." Rev. Cephas M. Mbewe of the Garden congregation chaired this committee.

While this report agreed with the last Synod recommendations, resolutions and divisions among ministers, it denied allegations that there were two camps of ministers in the Church. The committee called such allegations "mudslinging" against pastors. However, the committee gave a number of reasons for the divisions and why their fellow pastors and the members had labelled some pastors as "Pentecostal/charismatic."

Firstly, the divisions amongst pastors and name-calling were believed to be a result of their spiritual life and an approach to ministry. The report highlighted that some ministers were committed to a good Christian life: praying, fasting and reading the Word of God. On the other hand, other ministers were said to be committed to womanizing wherever they were sent.

Secondly, the report said that other ministers only maintained the status quo of their work and were not creative and sensitive enough to their members' needs. Their role was to guard against any deviation of the Church from its tradition as it was at the time of "Umwini" (ownership). This group felt insecure and vowed not to allow any new practices to creep into the Church.

Thirdly, the report addressed the preaching of the Word of God. Some ministers were accused of not condemning sin, but telling people wonderful things about heaven. To them, pointing out adultery, witchcraft, hatred, and gossip was tantamount to destroying the Church, while the other group could freely preach - rebuking sin, exhorting and transforming the lives of many members.

Fourthly, accommodation of terms like "Alleluia" and "amen" during preaching divided the ministers. Those fond of such expressions became known as "Pentecostal pastors."

Furthermore, there was the question of a Reformed identity of worship. Some pastors viewed "Reformed worship" to mean cold, stereotyped, dogmatic, inactive and pastor-centred worship. The committee said that, among pastors, this understanding was old fashioned as, by 2002 , the Church was challenged to focus on life-giving and transforming worship.

In summary, the 1996 and 1998 Synods accepted that the Church was facing new challenges, mostly Pentecostal/charismatic tendencies that needed to be addressed. The 1996 and 1998 reports did not address the conflict with neither a conflict resolution theory nor a transformation process in mind. The Synod leadership made no analysis of the contextual influence leading to the problem of Pentecostalism. The report was initiated without an in-depth understanding of the political, economic, and social context of the Pentecostal practices in question. During the two Synod meetings, the Church's leadership did not make an analysis of the degree to which the Pentecostal tendencies would make an impact on the RCZ. 
After the 1998 Synod meeting, the influence of Pentecostal tendencies and practices continued and grew. Almost a month after the 1998 Synod meeting, confusion raged at the Garden congregation. Twelve elders who did not believe in any new forms of worship resolved to remove their pastor, Rev. Cephas M. Mbewe, by force (Correspondence: Chelstone Presbytery 11 October 1999; Ezekiel Phiri 22 October 1998; Garden congregation 11 November 1998; Luka Zulu 10 October 1998; Sinai Choir 28 August 1998; Synod Actuarius 18 October 1998, 28 December 1998, 22 February 1999, 8 June 1999, 15 September 1999).

The divisions and squabbles continued in many other congregations, especially within Lusaka - at Lilanda, Matero, Chaisa, Mandevu and Chawama, to mention but a few. These problems continued in the Church until the Synod of 2000.

The 2000 Synod meeting took place against the background of growing divisions in the Church. Times of Zambia (9 May 1997; 31 January 2000; 8 February 2000) and Zambia Daily Mail (26 June 2000) carried stories about the mode of worship, such as "RCZ wrangles rage;" "RCZ factions row deepens," "300 members break away," "Reformed Church splits." Tensions amongst the pastors and elders were already high as they went to this meeting, which was held at the Mphangwe congregation from 21 to 25 August 2000, with the theme, "Church renewal through unity in diversity."

In 2000, the Synod resolutions on Pentecostalism resulted in more misunderstandings among the pastors, as well as between the Synod leadership and congregational members (Document: The State of Affairs in the RCZ: January 2001). According to the RCZ Synod Pastoral Letter of 2000 sent to all congregations, Synod had accepted praise and worship activities during Sunday services and mass praying. It was further said that a committee would be established to formulate the guidelines in order to incorporate these new developments in the liturgy. On 15 September 2000, the Actuary wrote to all congregations and pastors asking them to disregard Synod's decision, as contained in the Pastoral Letter that the General Secretary, Rev. Moses O. Kanyenda had written (Correspondence: Rev. H.D. Nkhoma, 15 September 2000). He regarded the contents and resolutions on Pentecostalism as a misrepresentation of the Synod's resolution (Mwa kalata iyi ndifuna kudziwitsa azibusa ndi mipingo yonse kuti kalata ya ubusa imene inatumidzidwa ili ndi colakwa pa mfundo ya CHIPEMBEDZO. Mfundo ya Synod ili motere). This letter directed all pastors and congregations to disregard item 12 in the Pastoral Letter with immediate effect. He wrote saying that, after a lengthy debate on the issue of Pentecostalism, Synod resolved the following (Correspondence: Rev. H.D. Nkhoma 15 September 2000):

"A committee comprising for and against Pentecostalism be appointed to look into this issue thoroughly and come up with a balanced thought.

"The committee should advise the Church whether to have one liturgy or more.

"The appointed committee should report their recommendation to Synod for approval or rejection."

Nkhoma pleaded with the congregations and pastors not to deliberately violate this resolution. He further warned all members and pastors that anyone found doing so would face disciplinary measures (Conde, conde tisapotoloze mfundo iyi ku mipingo yathu. Tisadzilowetse dala pa bvuto limene tikadapewa. Mbusa aliyense, komanso mpingo uli wonse opotoloza mfundo iyi ya Synod apalamula mlandu).

Following the 1996, 1998 and 2000 Synod recommendations and their resolutions, the 2000 Synod's difference of opinion between the Pastoral Letter and the subsequent letter that the actuary wrote to refute what the Pastoral Letter had said about praise and worship and mass praying, caused havoc. The misunderstanding in the Synod leadership of the 2000 Synod 
resolution resulted in many divisions among congregational members. In 2000, after the August Synod meeting, the state of affairs in the RCZ became known. The Church needed to take drastic and urgent measures to avert chaos. The situation in most of the Lusaka-based congregations was getting out of hand.

\section{0.}

\section{THE MARCH 2001 EXTRAORDINARY SYNOD MEETING}

This was one of the most extraordinary Synod meetings in the RCZ's history. The venue was the Madzimoyo congregation, one of the oldest mission stations that missionaries had established in the Eastern Province of Zambia. It is approximately 500 kilometres from Lusaka, the capital city of Zambia. The meeting took place from 2 to 4 March 2001. The delegates to this meeting were those who had attended the August 2000 Synod. Also extraordinary in this Synod meeting was the large number of observers who volunteered to attend. The moderator, Rev. Peter Ndhlovu, the general secretary, Rev. M.O. Kanyenda and other ministers who were perceived to support and promote Pentecostal practices in the Church, did not attend this meeting. This meant that the vice-moderator, Rev. Dr. Edwin Zulu substituted as acting moderator of this Synod meeting.

This Extraordinary Synod Meeting had one item on the agenda: "The way forward for the RCZ." The deliberations centred on ministers who abrogated the RCZ's traditions and doctrines. Article 4 of The constitution, bylaws and procedures of the RCZ (2004:3) reads:

"The RCZ is founded on the Bible, the holy and infallible Word of God. Its doctrine is

contained in the Doctrinal Standards namely the Belgian Confessions, the Heidelberg

Catechism, and the Canon of Dort (1618-19) and its liturgy shall conform to God the father,

the Son, and the Holy Spirit as the centre of worship".

The constitution, bylaws and procedures of the RCZ, Article 14(2) (2004:8) reads:

"A minister, who, regardless of the responsibility bestowed on him (her) fails to comply and/

or observe the oath of allegiance and the Church doctrine may be excommunicated which

leads to the withdrawal of the license".

During this Extraordinary Synod Meeting, this framework of understanding influenced the decision-making process. Names were presented and those in attendance were called upon to exculpate themselves and to make a public declaration for, or against, the RCZ. It was a structured Synod meeting with only one closed-ended question, the answer to which was either Yes or No. The question was, "Are you RCZ/Dutch or Pente?" 8

When all the names were scrutinized, the Synod resolved that all those ministers who involved themselves with Pentecostal practices be expelled and excommunicated from the Church.

The Church hailed the resolutions passed at this Synod. Members welcomed the Synod's decision with mixed feelings as some viewed the decision as harsh and un-Christian. Two days later, on 6 March 2001, a break-away Church, the BIGOCA, was launched and drew its membership from the RCZ under the leadership of Rev. Peter R. Ndhlovu as its bishop.

In conclusion, the precursors of the Pentecostal and charismatic tendencies in the RCZ had been pastors and members within the Church. The differences of worship that pastors and their supporters started to bring into congregations as from 1996 onwards, created a platform for its popularity and practices. Subsequent to this, other elements, such as speaking in tongues, singing of choruses, sessions of healing, etcetera, started to gain recognition and acceptance among members as evidence of transformation.

8 The term "Pente" was an abbreviated name ascribed to those congregants who were believed to practice Pentecostalism. It was more vernacular amongst many members and easier to use than the full terminology of Pentecostals. It was a distinguishing designation between members of the RCZ and those in the group with new Pentecostal/charismatic tendencies. 
It is ironic that at the RCZ's 2008 Synod, the issue that was the bone of contention of the conflict and expulsion, i.e. mass prayers, was allowed to be part of the liturgy (RCZ Pastoral Letter of the $25^{\text {th }}$ Synod Conference 13-17 August 2008; Soko 2010:159-160).

Having discussed the Pentecostal tendencies in the Church according to various documents, the following section will examine the saga around the RCZ Mtendere congregation from 1996 to 1999.

THE SAGA OF THE MTENDERE CONGREGATION: 1996 - 1999

This section explores the saga of the Mtendere congregation's from 1996 to 1999. It serves to illustrate events in a specific congregation in more detail that culminated in the first schism in 1999 and as such set the scene for the much bigger split described above. In this section, the researchers will limit the discussion to those events that led to the saga that resulted in the excommunication of the minister. Consequently, a new Church, called the "Christian Reformed Church," was formed.

\subsection{A brief background of the Mtendere congregation}

In 1979, the Mtendere congregation was established in the Mtendere compound in Lusaka. It was the sixth congregation that was established in Lusaka after Kamwala in 1935 (RCZ Synod Minutes: Western Synod, 31 October to 7 November 1993). At the time of this congregation's problems, it belonged to Chelstone Presbytery, in which there were 11 congregations, including Mtendere. Many other ministers had served this congregation. On 10 March 1996, Rev. Mabvuto Ngoma was released from Mtendere when the Council of Churches of Zambia (CCZ) appointed him as relief coordinator for the refugees (RCZ Chelstone Presbytery extraordinary meeting minutes 1 February 1997).

As usual, the congregation was left without a resident minister. In the RCZ, two systems work hand in hand. When a congregation wishes to call a minister of their own choice, the Synod leadership does not interfere. On the other hand, when Synod transfers a minister to any of its congregations, it too does not seek approval from the congregations. Synod sent Rev. Amos Ngoma to this congregation in August 1996 and he was inducted on 10 November 1996 (Dziwani Vol. 14:31; RCZ Chelstone Presbytery extraordinary meeting minutes, 1 February 1997).

\subsection{The beginning of problems at the Mtendere congregation}

The problems at Mtendere started as a constitutional matter between the elders' council and Chelstone Presbytery's leadership about their refusal to have been given a minister by Synod. The elders' council, held on 20 September 1996, resolved not to accept Synod's decision. The Chelstone Presbytery was forthwith notified of their resolution (RCZ Chelstone Presbytery extraordinary meeting minutes 1 February 1997). In short and by implication, the council rejected Rev. Amos Ngoma. Now, the Presbytery was in an awkward position as it felt it could not reverse the Synod's resolution. This resulted in misunderstandings and witch hunting between the elders and the Presbytery leadership.

On 13 October 1996, a meeting was called between the Mtendere elders and the Presbytery leadership, the aim of which was for the Presbytery to discuss the way forward with the elders. At this meeting, the elders maintained their position of refusal. 29 voted against the Synod's decision and three voted in favour of the congregation's acceptance of the minister. This stance of the elders forced the Presbytery leadership into action. The Presbytery disciplined the 29 elders who voted against the minister's transfer and did not accept the Synod's decision to place Rev Amos Ngoma at Mtendere. The Presbytery ruled that for four years, none of them could 
hold any position in the congregation. So far the Presbytery therefore supported the Synod.

Arising from this decision of the Presbytery, the congregation was compelled to receive Rev. Amos Ngoma as a resident minister. He was inducted on 10 November 1996 amid strife between the rival factions in the congregation.

The suspended elders did not accept the verdict of their Presbytery leadership and appealed to the Synod leadership to intervene (Correspondence Synod Secretary 27 November 1996; Chelstone Presbytery 4 December 1996). They challenged the decision to place anyone in the $\mathrm{RCZ}$ on a four-year suspension period as being unconstitutional. This appeal completely changed the level of conflict. The elders' actions by writing to Synod without consulting them upset the Presbytery leadership.

\subsection{RCZ leadership differences and the Mtendere congregation}

It is now clear that both the Synod and the Chelstone Presbytery's leadership had a major role in the conflict at Mtendere. The Presbytery leadership felt that the Synod leadership had betrayed them, as the Synod received direct complaints from the expelled elders, who were at this stage more in agreement with the Synod leadership. On the other hand, the Synod leadership felt that they were demeaned by both the Presbytery and Rev. Amos Ngoma, who had no kind words for the Synod leadership.

On 19 April 1997, the Synod leadership called a meeting to which the groups in the Mtendere saga were invited. The two faction groups were the Mtendere congregation and the Presbytery leadership. This meeting was initially fruitful insofar as the resolution was concerned. The resolution (first decision) was: "for peace and Christian testimony the offending elders should be forgiven, the suspension is lifted. They should be full members of the Church and can be chosen on any committee. Rev A Ngoma should continue as pastor of the Church and current elders should continue with their duties" (RCZ Mtendere Congregation report Sept 1998). For whatever reasons, those elders, who were previously on suspension, regarded this decision as unacceptable. They started slinging insults at Rev Ngoma and the Synod leadership. They stormed into the meeting, halted the proceedings and manhandled the chair of the meeting, deputy moderator, Rev. Japhet Ndhlovu.

In the absence of Rev Ngoma Rev Ndhlovu continued with the meeting and because of the pressure from the anti-Amos Ngoma group, the meeting rescinded its earlier decision. Their new resolution was as follows (RCZ Mtendere Congregation report Sept 1998):

"Rev Ngoma should be transferred and leave the Church the following day.

"Synod Moderamen should conduct the release (chimasulo) instead of Presbytery.

"Rev. Ngoma should not be allowed even to preach a farewell message to the Church.

"Current elders (supporting Rev Ngoma) to be dissolved"

Two members of the moderamen, in person, communicated the above resolution to Rev Ngoma. On the morning of 20 April 1997, as resolved in the meeting, the moderamen went to the Mtendere congregation to release Rev. Ngoma. Both Rev Ngoma and his elders rejected the second decision.

Arising from this deadlock, the situation at Mtendere was now out of control. The moderamen's failure to release Rev Ngoma fuelled widespread condemnation in the Church and Chelstone Presbytery leadership became frustrated and outspoken against the Synod leadership.

As though that was not enough, Rev Ngoma also had the courage to call Synod leadership "hypocrites" and "corrupt in their exercise of duty". This unbecoming behaviour of Rev. Ngoma annoyed the Synod leadership. The first measure that Synod took on 6 May 1997, was to dissolve the Presbytery leadership and, secondly, to transfer Rev. A. Ngoma to the Beteri congregation in the Eastern Province (Correspondence: Synod Secretary (office) 6 May 1997; Daily Mail 28 April 
1997; Times of Zambia 24 April 1997).

As the Synod leadership tried to find a way of diffusing the Mtendere problem, and as wrangles and church closure persisted in the tug of war, Rev. Ngoma and his supporters opted to start worshipping in a rented unfinished building. This further deepened the crisis, because this splinter group continued to identify themselves as members of the RCZ, contrary to the constitution of the Church. The group called itself "RCZ Mtendere East."

By October 1997, relative peace had been restored at Mtendere. The new office-bearers (the elders and deacons) were chosen and confirmed. Arising from this breakthrough, the congregation now had to call a minister and Rev. Andrew B. Zulu from the Merwe congregation in the Eastern Province was called. He was inducted on 24 May 1998 (RCZ Synod Report 21-29 August 1998).

From December 1998 to April 1999, the newly instituted Presbytery leadership made every effort to reason with both groups who now seemed to belong to two separate congregations. Rev. Ngoma's group refused to again merge into one congregation. They demanded to be established as one of the RCZ's congregations. The Mtendere group was sceptical of bringing back the break-away group who had already shown interest of becoming a Church. Arising from this, the Presbytery leadership resolved (without Synod's approval) to establish a new congregation called "Mtendere East" on 24 April 1999, followed by the induction of Rev A. Ngoma the next day, 25 April 1999 (RCZ Chelstone Presbytery extraordinary meeting minutes, 1999). The June 1999 Synodical Executive Council meeting rejected the Chelstone Presbytery's report on the establishment of the new congregation. The Presbytery's leadership committee was directed to revisit their decision and report to the Extraordinary Synod, which was held from 8 to 13 August 1999 at the Mphangwe congregation in the Eastern Province.

At this Extraordinary Synod Meeting (RCZ Pastoral Letter, 8-13 August 1999), the Mtendere problem was discussed and concluded; Rev. Ngoma was indefinitely suspended for gross insubordination. His members from the Mtendere East congregation were given three months to return, failure of which, they ceased to be members of the RCZ. Arising from the resolution of the 1999 extraordinary Synod meeting to suspend Rev. Amos Ngoma directly meant that his newly established congregation and members were detached from the RCZ. Since then, Rev. Amos Ngoma has remained the only ordained minister, and now has the title of bishop. They call themselves the Christian Reformed Church.

\section{2.}

\section{CONCLUSION}

The researchers have discussed the 1999 and 2001 schisms in the RCZ descriptively. The aim was to understand what caused the schisms from that vantage point. What the various documents highlighted was the reality of Pentecostal / charismatic influences and the failure of the RCZ leadership to provide an environment conducive for dialogue and consistency in handling the issues. Leadership was more often than not divided. In both cases, the claims or statements about the situation, as well as the state of affairs at the time of the infighting in the Church, show how antagonism between the ministers and church councils developed. It needs to be pointed out that the evidence produced above, focuses on the leadership factor in the schisms. More factors are involved (Soko 2010).

In retrospect, the schism's bigger picture has more nuances to it than what was dealt with in this research. The answer to the question: What led to the schisms and how did it happen? can only be fully answered when the RCZ's history and identity is understood, as well as the global contextual changes that have taken place and literally transformed Zambian society and culture (Soko 2010:81-120). Pentecostalism was born at the beginning of the 20th century in 
circumstances not much different from what is experienced in Zambia and in many countries around the world. Its style, music and ethos address the realities of our times (Cox 1995, Kalu 2008). The RCZ leadership is modeled on the missionaries' and local political leadership and ethos of the independence and post-independence periods. It was divided according to the lines of conflict that ran through the Church, i.e. Dutch and Pente. In a sense, the schisms were unavoidable; they played out like a tragic drama. This was also confirmed by the empirical research done in Lusaka (Soko 2010: 121-160).

The rise of Pentecostalism in Zambia is not the RCZ's problem alone. Other denominations are experiencing the same phenomenon that threatens the once cherished monopoly of the mainline Churches. The theological phenomena that play a role need to complement this research. What struck the researchers was that this aspect of the schism was not addressed by leadership. The goal of the research was to have a solid descriptive basis from where subsequent research can deal with the obvious theological challenges facing the church. It did highlight the fact that the Church lacks strategies to resolve conflicts in a win/win way as well as the ability to understand and address the context and deeper causes of the conflict.

\section{REFERENCES}

(The) constitution, bylaws and procedures of the RCZ. 2004. (2 $2^{\text {nd }}$ ed.) Bloemfontein: Drufoma.

\section{Correspondence:}

Chawama congregation, 18 January 2001.

Chelstone Presbytery, 4 December 1996, 11 October 1999, 12 January 2000.

Garden congregation, 11 November 1998.

High Court of Zambia: correspondence, 11 May 2000

Mbewe, Rev. Cephas M, 28 March 1996

Ndhlovu, Rev. Japhet 22 February 1996.

Nkhoma, Rev. H.D., RCZ Actuary, 15 Sept 2000.

Nkhuwa, Rev. Rodgers, 19 March 1996.

Paradise congregation 26 December 1995.

Phiri, Ezekiel, 22 October 1998

Sinai Choir 28 August, 1998

Synod Actuarius, 18 October 1998, 28 December 1998, 22 February 1999, 8 June 1999, 15 September 1999.

Synod Secretary (office), 27 November 1996.

Synod Secretary (office), 6 May 1997.

Zulu, Luka, 10 October 1998.

Cox, H. 1995. Fire from Heaven: the rise of Pentecostal spirituality and the reshaping of religion in the twenty-first century. New York: Addison-Wesley.

Daily Mail: June 26, 2000, April 28 1997, April 26, 1999, June 12, 2000. (Also known as Zambia Daily Mail)

Document: Jan 2001. The state of affairs in the RCZ.

Dziwani , Vol 7:20, January/February 1994; Vol. 11:28, 1996; Vol 14:31.

Heitink, G. 1999. Practical Theology. History. Theory. Action domains. Cambridge, U.K.: Eerdmans.

Hendriks, H.J. 2004. Studying congregation in Africa. Wellington: Lux Verbi BM.

High Court of Zambia 11 May 2000.

Kalu, O. 2008. African Pentecostalism: an introduction. New York: Oxford.

Missionalia 35:3. The Nov 2007 issue dealt with Pentecostalism.

National Mirror No 869 January 27 - February 2, 2001.

(The) Post: 7 March 2001

RCZ Chelstone Presbytery extraordinary meeting minutes: 1 February 1997; 1999.

RCZ Mtendere Congregation report, Sept 1998.

RCZ Synod Minutes, 1991, 1996, 1998, 1999, 2000, 2001, 2002, 2004, 2006 and 2008. Lusaka. 
RCZ Synod Minutes: Western Synod, 31 October to 7 November 1993.

RCZ Synod Pastoral Letters: 13-18 August 1996; 13-17 August 2008.

RCZ Synod Reports, 21-29 August 1998.

RCZ Synodical Executive Committee Minutes 4 to 5 June 1997.

RCZ Synodical Executive Council, Pastoral letter, June 2006.

Soko, L. 2010. A Practical Theological assessment of the schisms in the Reformed Church in Zambia (1996-

2001). Unpublished DTh dissertation, Stellenbosch University. http://hdl.handle.net/10019.1/5454 downloaded 15 Dec 2010.

Times of Zambia, April 24, 1997; May 9, 1997; January 31, 2000; February 8, 2000; January 2, 2001.

Verstraelen-Gilhuis, G. 1982. From Dutch mission to RCZ. Wever: Franeker.

\section{KEY WORDS}

Reformed Church in Zambia

Schism

Pentecostalism

Church leadership in Africa

Church conflict

The Bible Gospel Church in Africa

Identity.

\section{TREFWOORDE}

Gereformeerde Kerk in Zambië

Kerkskeuring

Pentekostalisme

Kerklike leierskap in Afrika

Kerklike konflik

The Bible Gospel Church in Africa

Identiteit.

Prof HJ Hendriks, Faculty of Theology,

171 Dorp Street,

7600 Stellenbosch, South Africa. hjh@sun.ac.za

Dr Lukas Soko, RCZ Kalulushi Congregation,

PO Box 260246,

Kalulushi, Zambia. lukas.soko@yahoo.com 